\title{
How to manage flood forecasting in a catchment with high flood risk - experiences from the Emscher
}

\author{
Georg Johann ${ }^{1, a}$ and Alexander Hartung \\ ${ }^{1}$ Emschergenossenschaft, Floodriskmanagement Department, 45128 Essen, Germany
}

\begin{abstract}
The Emscher area is a basin of $865 \mathrm{~km}^{2}$, which includes nearly 2.3 million inhabitants. According to the average of 2.700 inhabitants per $\mathrm{km}^{2}$ nearly $60 \%$ of the basin's surface is sealed. 100 years of coal mining shaped the basin significantly. Due to that open channel system, the Emscher river shows a very quick reaction on precipitation. What does that mean for our flood forecasting? We have to record our data of the river gauges in an adequate time interval, that is usually $1 \mathrm{~min}$. We have to import this recorded data from the gauges in our timeseries database every 5 minutes. In several other time intervals we're getting our precipitation data, the radar data and the available numerical weather forecast from the German Weather Service. All this serves as input data for multiple model runs. The flood forecasting models perform continuous calculations every half an hour. All in all we're offering an hydrological forecasting service for the operational branch of our organization so that they can handle the occurring problems. If necessary we're performing this duty in a shift work system, so that we can offer a 24 hours service as long as needed.
\end{abstract}

\section{Task of the Emschergenossenschaft}

In the Emscher region, the demands of people and of nature are at odds with one another. To balance these demands in a sustainable fashion is the task of the Emschergenossenschaft which is responsible in the region (fig. 1), not just for wastewater treatment and the multi-generational Emscher redevelopment project with the natural redesign of open wastewater channels, but also particularly for flood management. The $865 \mathrm{~km}^{2}$ large catchment area of the Emscher is located in the largest conurbation in Europe between Dortmund and Duisburg, home to 2.3 million people. It is characterised by a very high population density and therefore has the potential to sustain considerable damage in the event of floods. Added to this is the fact that coal-mining has lead to to the creation of dangerous, potential floodplains with large water depths.

Flood management to deal with this is one of the central, statutorily defined tasks of the Emschergenossenschaft. In its regions, the association is bound to practice flood water management that is carefully considered from a water management, ecological, economic and social viewpoint [1]. In this respect, both technical flood protection measures such as dikes, pumping stations and flood control reservoirs as

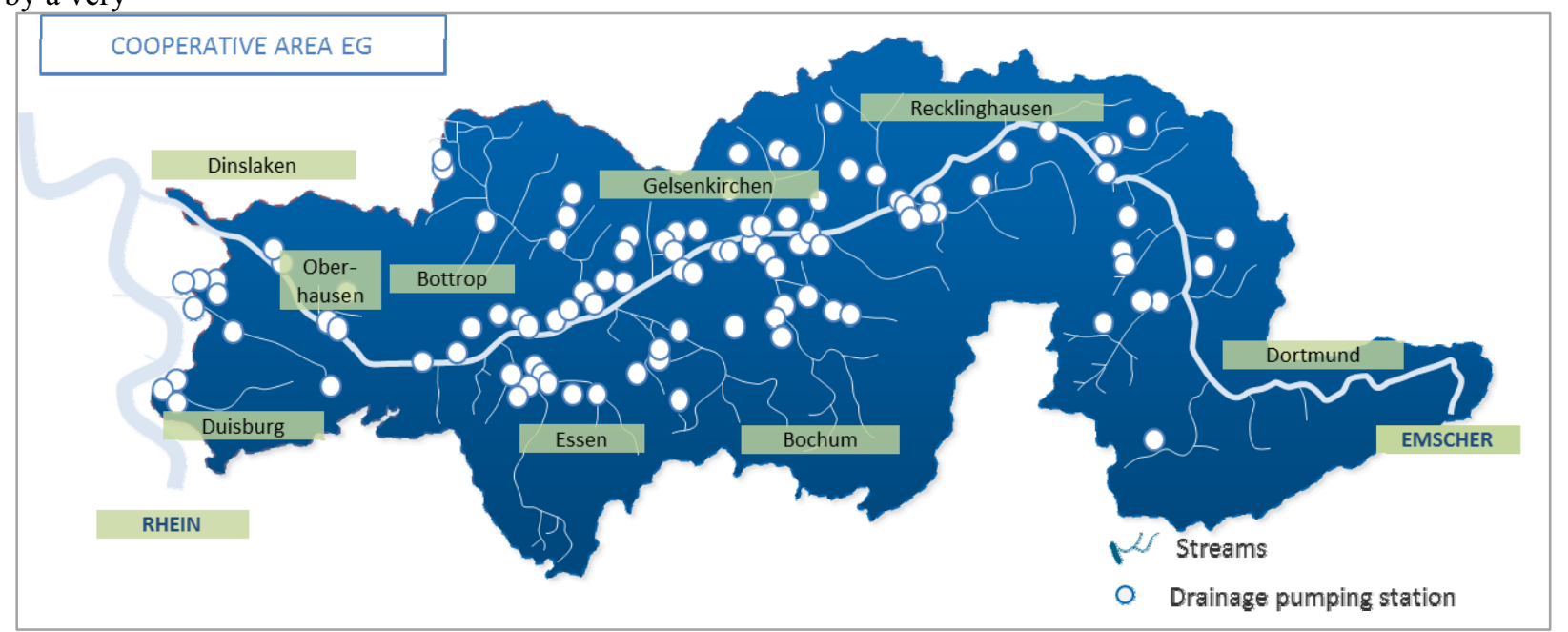

Figure 1. The Emscher basin and some tributary streams

$\overline{{ }^{a} \text { Corresponding author: johann.georg@eglv.de }}$ 
well as decentral management activities (reservoirs in the catchment areas, connection to the river meadows or decouple lof runoff-influencing surfaces from the sewer network) are taken into consideration.

\section{Runoff characteristics of the Emscher}

Since the middle of the 19th century, underground coal mining has caused grave drainage disruptions in the watercourses and wastewater system in the region under consideration. At the start of the 20th century the Emschergenossenschaft created a technically defined watercourse system through straightening, building embankments and expanding the system to have open sewage channels. In turn, this guaranteed industrial growth in the catchment area of the Emscher.

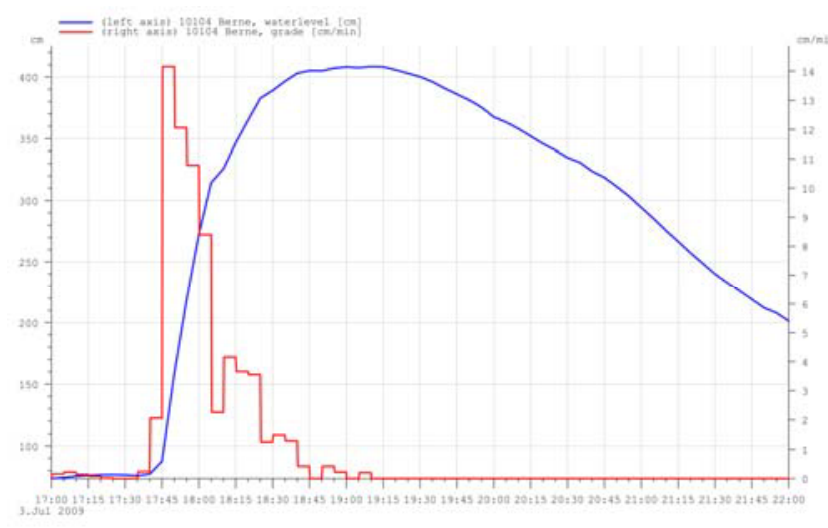

Figure 2. Flood wave of the river Berne from the 3rd of july in 2009. red: grade of water level rising [ $\mathrm{cm} / \mathrm{min}$ ]; blue: water level

The increasing degree of soil sealing in the subsequent years lead to an aggravated runoff situation with quickly rising, sharp flood waves. In the Emscher region, in particular, short bursts of violent heavy rain lasting two to twelve hours generate flood waves. One can often observe a rapid rising of the waterlevel that achieves ratios about $150 \mathrm{~cm}$ in 15 minutes or nearly 3,5 $\mathrm{m}$ per hour. See the following two figures representing an event from the 3 rd of july in 2009. In the first figure the flood wave of the river Berne, a big tributary of the Emscher, shows ratios about $185 \mathrm{~cm}$ in 15 minutes or 325 $\mathrm{cm}$ in 60 minutes.

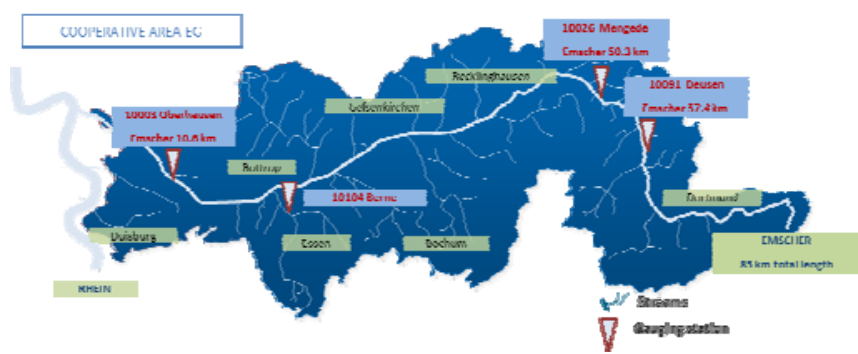
basin
But the Berne is not the only river showing that behaviour, the Emscher itself reaches similar values in the ascending part of a flood wave.

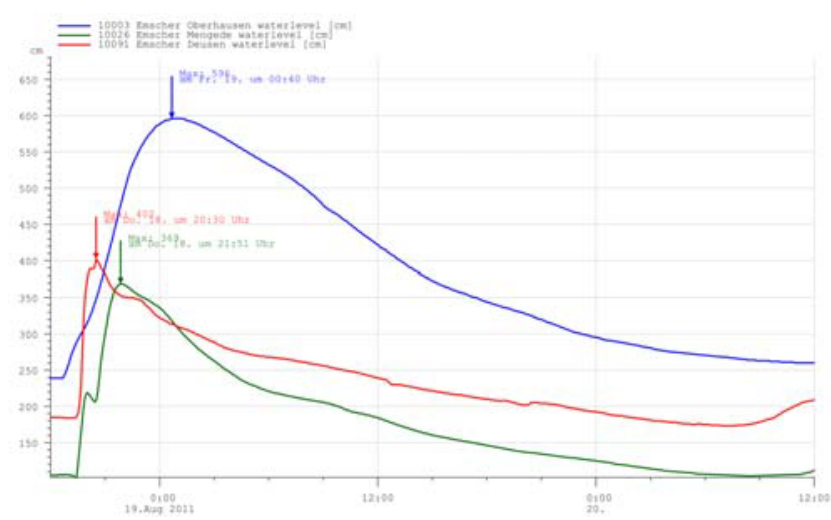

Figure 4. Flood wave rushing down the Emscher at the 18th of august in 2011, black: precipitation; red: Emscher gauge at

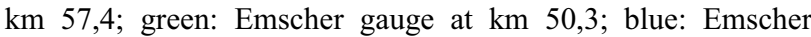
gauge at $\mathrm{km} 10,6$

Moreover figure 3 shows the velocity of a flood wave rushing from Dortmund to Oberhausen in about 6 hours or $10 \mathrm{~km}$ per hour. The event has high intensities (about $75 \mathrm{~mm} / \mathrm{h}$ ) and lasts half an hour. This is a typical summer thunderstorm. This event proceeds westwards, that is against the flow direction of the Emscher. In figure 3 the analysed gauging stations are illustrated. Gauging station number 10003 is situated at the Emscher $10.3 \mathrm{~km}$, number 10026 at Emscher $50.3 \mathrm{~km}$ and station 10091 at Emscher $57.4 \mathrm{~km}$. Additionally the tributary Berne from figure 2 is marked. The three timeseries in figure 4 illustrate the velocity of the flood. In the upper part of the Emscher (between river $\mathrm{km} 57.4$ and 50.3) the wave travels with $5 \mathrm{~km}$ per hour and downstream (from river $\mathrm{km} 50.3$ to 10.3 ) it increases up to $11 \mathrm{~km}$ per hour. What does that mean for our flood forecasting?

\subsection{Hydrometric data}

We have to record our data of the river gauges in an adequate time interval, that is usually $1 \mathrm{~min}$. We have to import this recorded data from the gauges in our timeseries database every 15 minutes, including an elementary automatic control of the raw data. This control includes 5 simple checking algorithms, altogether the increase the data quality significantly. In a first step these algorithms control the hydrographs in our intranet Web site, secondary they are implemented in our online data feed for the hydrologic simulation models. In detail we check the raw data on the appearance of gaps, outliers (min and max), sudden steps, constant values and values that show to high variations concerning the average in a certain time interval. All these tests run exactly in the mentioned order, which is very important to comply with, otherwise these tests will remain useless. Last not least the checking algorithms need some specific parameters that have to be adapted to the characteristics of each gauging station.

The flood forecasting models perform continuous calculations every half an hour. In several other time 
intervals we're getting our precipitation data. Based on a collaboration with the German weather service we also get data from the German Weather Service. Providing this data for eleven waterboards in north rhine westfalia we build up an data exchange platform. On this platform there are 14 radar products from 3 radar stations, 5 numerical weather forecast models including ensemble predictions and one climate data product available. In order to increase the quality of the radar data, all the participating waterboards contribute online data from their precipitation gauging stations, so that the weather service can improve the precipitation corrected online radar product called "Radolan". Simply demanding all this data from the weather service causes about $3 \mathrm{~GB}$ of traffic, hosting and providing this data for 11 waterboards generates even a lot more traffic. This data platform provides the actual data and has an archive function by storing the last three months in forms of a circular buffer. Decreasing our maintaining effort, the hosting of this data is fulfilled by an external service provider.

\section{Flood management and flood response requirements}

The Emschergenossenschaft created flood management concepts [2], which are being developed further and adapted to new issues. They are based on risk-minimising measures, on quantified flood forecasts and derived precautionary behaviour, on an equal footing with technical, structural flood protection. Risk analyses and evaluations are performed for flood precautions. These represent the foundations for measures to reduce risks before a flood event; they are also however indispensable information for a flood response [3].

The key element of flood management is an operational early flood warning system. And this requires data of river and rain gauges in in high time density.

Flood forecasts for the divisions of the Emschergenossenschaft are created in the form of daily flood situation reports, which are provided by the hydrologists on duty (who alternate weekly) on the inhouse Intranet. These contain the current weather and flood situation with a forecast for the next two days so that the weekends are covered too. When the situation report is drafted, all required data and forecast sources are checked specifically to ensure they are up-to-date. These are the runoff and precipitation measurement data, the forecasts of the German weather service, radar images and model results.

In the event that warning thresholds in the measurement or forecast data are exceeded for the service's flood preparedness and flood deployment teams, corresponding signal lights are assigned (fig. 5). The warning thresholds are defined by the flood deployment teams and vary from watercourse to watercourse due to the locally flood risk.

In the case of a yellow or red light, automatic warnings are sent within the system to a selected group of personnel, by email and via SMS. In critical situations, district preparedness teams, and if required also the superordinate flood control centre at the
Emschergenossenschaft, are called in and these parties constantly exchange information about the flood situation in order to be able to take the required measures on site, properly and in good time.

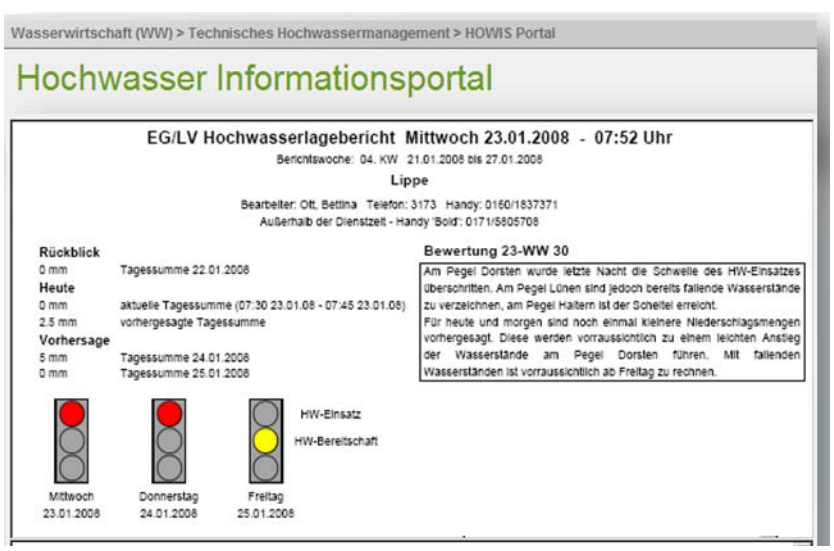

Figure 5. Example of daily report flood warning

\section{Supporting flood management}

\subsection{The flood forecasting system HOWIS}

The forecast platform which has been described as a critical component of the flood management concept is integrated in a comprehensive flood information system. A flood forecast model exists for the Emscher. This hydrological regional model is automated and runs in online mode with a time increment of 6 minutes so that the flood risk can be constantly monitored.

The model input data includes, inter alia, 58 terrestrial precipitation measurements by the association itself. The short response time required for the densely populated catchment areas with their high degree of soil sealing necessitates a precipitation distribution that is highly dispersed both spatially and temporally; consequently radar data from the German weather service is also used as a model input variable [4]. Therefore, two simulation runs are always performed to calculate the current situation. They provide the starting conditions for the flood forecast, which uses the precipitation forecasts of the German weather service as an input variable.

The quality of the flood forecast, i.e. the accuracy of the forecast levels and the timing of the flood peak depends on different factors. Firstly, there are uncertainties inherent in the system regarding the generalised description of an anisotropic catchment area in a hydrological model. Added to this are uncertainties regarding the simplified simulation of the diverse processes that lead to a flood wave ([5], [6]). Therefore, the quality of the flood forecast is subject to consistent quality control and enabled by the subsequent reproducibility of forecasts in the flood information system.

However, the quality of precipitation forecasts is much more significant for reliable flood forecasts [7]. The flood information system therefore also uses, along with deterministic weather forecasting products (precipitation forecast with a model run), the ensemble 
forecasting system COSMO-LEPS (Limited-area Ensemble Prediction System) in the form of 16 equally probable, meteorologically speaking, ensemble forecasts as a model input variable [8]. All the forecasting products used in the flood information system are provided by the German weather service. The ensemble precipitation forecast serves to supplement the deterministic forecast. The 0.75 quantile of the COSMO-LEPS product achieves usable results (fig. 6). Events tend to be underestimated rather than overestimated. The flood peak is forecast too late most of the time. Previous experience in practice has shown that from the point of view of the runoff forecast, the 16 ensemble forecast calculations are not all equally probable [9].

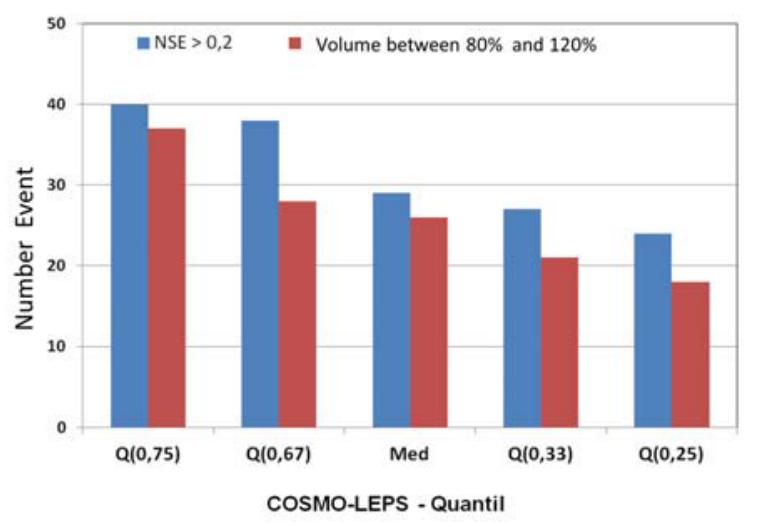

Figure 6. Quantils of 90 forecast events at Emscher gauge

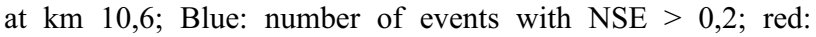
number of event with forcasted volume deviation $+-20 \%$ from the measured flood wave

The deterministic precipitation forecast of the German weather service also contains noteworthy uncertainties. This is particularly the case with the forecasting of convective precipitation. Here it is not just a question as to how much rain will fall when and in what time frame, but also, and particularly, where it will fall. The movement of storm cells is dependent on numerous unpredictable parameters. For the tributaries of the Emscher with catchment area sizes of between $50 \mathrm{~km}^{2}$ and $100 \mathrm{~km}^{2}$, there are still too many open questions that are too hard to assess because of the uncertainties in precipitation forecasting. For example, the key question as to whether or not a catchment area will be affected by a strong precipitation cell. Therefore, automated flood forecasts are currently only performed for the Emscher itself. For the tributaries, forecasts are prepared as required; the rain input data is checked for plausibility and if required changed manually in terms of the precipitation quantity, its temporal distribution and its timing.

The flood risk is assessed daily by an expert and a situation report is provided for the operational systems in the in-house Intranet. Hydrological on-call services are also called in during ongoing flood events. For the duration of the flood, situation assessments are provided continuously to the flood control centre of the facility operation. Using the Intranet-based representation, it is ensured that all flood-protection-relevant divisions in the association's region are constantly informed. Only in this way is the optimal deployment of the operating teams possible.

The flood information system with its hydrometric information is linked with the Dike-Data-Service, which provides statements on flood risks.

\subsection{The Dike-Data-Service}

With the knowledge of the imminent flood level comes the question as to the consequences of the forecast flood event on the flood protection systems. The Emschergenossenschaft und Lippeverband operate around $220 \mathrm{~km}$ of dikes with settlement areas in the dike hinterland, which with degrees of development between HQ25 and HQ250 are located along different stretches of waterway. The Dike-Data-Service delivers information on these stretches of dikes.

The objective of the Dike-Data-Service is to support the early introduction of dike defence measures. Geometric data of the dike structures and stability inspections are linked with water levels in the watercourse.

In addition to the static offline information, the DikeData-Service also represents the current flood situation. On the one hand, using 40 level online measurements, water levels are transmitted to the dike stretches in 15 minute intervals and information on the current freeboard is provided. In addition the runoff forecasts for the Emscher are to be linked to the Dike-Data-Service: the forecast discharges are converted, using water-level discharge relationships, into water levels at the dike stretches, in order to represent the forecast flood risk and the risk to them respectively. This functionality is established as early as construction. With this, the DikeData-Service acquires a quick overview of the flood situation or risk in the association's regions. This information is hugely helpful when managing the deployment of personnel and initiating flood response measures.

In addition to the risk of overtopping, the risk of dike failure is represented. With a dike fragility curve, which illustrates the failure probability of the dike as a function of the water level, geotechnical aspects are integrated in the operational safety evaluation [10]. The system was previously tested with Emscher dikes ( $\mathrm{km} \mathrm{0.0-30.0)}$ and is to be extended to other stretches of dikes in the future.

By comparing this information with the areas protected by the dikes and the associated potential flood damage, flood risk evaluations can be performed. On this basis, the operational staff will receive important information on dike sections, which must be given particularly careful consideration in the event of flooding.

\section{Conclusion}

For an optimal flood response, it is desirable to have as much information as possible on the flood situation and on the stress of the flood protection systems, and to have this as early as possible. However, forecasts with a sufficiently high level of reliability cannot be issued for every catchment area. This applies particularly for fast 
reacting, small catchment areas that are above all responding to floods caused by heavy precipitation. In such areas, there is just 2 to 6 hours from precipitation to the flood maximum. That time frame is tight for flood response measures. A forecast for such areas is however particularly unreliable because the formation and movement of convective cells is dependent on many unpredictable parameters. Therefore, for most tributaries of the Emscher only qualitative forecasts are issued, which are constantly updated. The flood protection strategy assumes that the flood response is rarely possible during the event because of time constraints. Here the focus of flood management is placed on precautions. For larger catchment areas with longer concentration times, on the other hand, useful flood forecasts can be issued so that measures can be initiated as early as possible.

\section{References}

1. Grün, E. and Johann, G. (2012). Hochwassermanagement im urbanen Umfeld. In: Hochwasserschutz - eine Daueraufgabe: 42.Internationales Wasserbausymposium, Aachen (IWASA).

2. Emschergenossenschaft / Lippeverband (2003). Hochwasserschutz an der Lippe und an der Neuen Emscher. Emschergenossenschaft / Lippeverband, Dezember.

3. DWA Themen (2012). Schadensanalysen und Projektbewertung im Hochwasserrisikomanagement. DWA Themen T1, Hennef, July 2012

4. Johann, G.; Ott, B. and Treis, A. (2009). Einfluss von terrestrisch gemessenen und radarbasierten Niederschlagsdaten auf die Qualität der Hochwasservorhersage. Korrespondenz Wasserwirtschaft 2009 (2) Nr.9, 487-493

5. Ehret, U. (2012). (Un-)sicherheiten in der hydrologischen Modellierung und Vorhersage. Korrespondenz Wasserwirtschaft 2012 (5) Nr.6, pp.316-320

6. Johann, G. (2009): Softwareeinsatz zur Planung von Hochwasserschutzmaßnahmen in der Praxis. BfG Veranstaltungen 6/2009 Softwarelösungen für ein integriertes Hochwassermanagement, 70-76

7. Solomatine, D. P., Di Baldassarre, G., Kayastha, N. \& Shresta, D.L. (2013). Application of methods predicting model uncertainty in flood forecasting. Comprehensive Flood Risk Management. London 2013. pp. 389-395

8. Montani, A. et al. (2010). Seven years of activity in the field of mesoscale ensemble forecasting by the COSMO-LEPS system: main achievements and open challenges. Consortium for Small-Scale Modelling, Technical Report No. 19, Bologna

9. Horn, G., Johann, G. and Treis, A. (2012). Hochwasservorhersage mit den NiederschlagsEnsembleprognosen COSMO-LEPS - ein Praxistest für die Emscher. 3. Trierer Workshop zur $N-A$ Modellierung
10. Bachmann, D.; Huber, N. P; Johann, G. and Schüttrumpf, H. (2012). The integration of geotechnical dike reliability into operational flood management via fragility curves. Comprehensive Flood Risk Management, 2013, London 